\title{
Integrated Nutrient Management Studies on Growth, Yield and Quality Attributes in Chilli (Capsicum annuum L.)
}

\author{
M. Yogaraju*, V. Srinivasa, Y.M. Mahadevprasad and Devaraju \\ Department of Vegetable Science, College of Horticulture, Mudigere, University of \\ Agricultural and Horticultural Sciences, Shivamogga, Karnataka, India \\ *Corresponding author
}

\section{Keywords \\ Chilli, INM , Biofertilizers, Micronutrient mixture \\ Article Info \\ Accepted: \\ 18 January 2019 \\ Available Online: \\ 10 February 2019}

\section{A B S T R A C T}

A field experiment was conducted on "Effect of INM practices on plant growth, fruit yield and quality attributes in chilli at College of Horticulture, Mudigere during rabi season. Results revealed that, among the different treatments, the combination of Azospirillum + $\mathrm{PSB}+\mathrm{VAM}+\mathrm{KSB}+50 \% \mathrm{RDF}+\mathrm{MgSO}_{4}+$ Micronutrient mixture stimulated better response in terms of growth yield and quality attributes of chilli $\left(\mathrm{T}_{12}\right)$. The maximum plant height $(88.61 \mathrm{~cm})$, number of primary and secondary braches per plant (11.22 and 18.44, respectively), number of leaves (298.87), leaf area of plant $\left(10578.06 \mathrm{~cm}^{2}\right)$, leaf area index (3.92) and total dry matter (118.48 g/plant) were recorded in treatment $\mathrm{T}_{12}$. The same treatment also recorded maximum fruit length $(11.60 \mathrm{~cm})$, fruit girth $(4.80 \mathrm{~cm})$, fresh weigh of fruit/plant $(268.89 \mathrm{~g})$, fruit yield /plant $(658.67 \mathrm{~g})$, yield/ plot $(13.75 \mathrm{~kg})$ and yield/ha (22.92 t/ha). Quality parameters like chloropyll content in leaves (79.74 SPAD units), ascorbic acid content $(141.27 \mathrm{mg} / 100 \mathrm{~g})$ and capsaicin content $(0.39 \%)$, were also recorded maximum in the same treatment. Thus, combined use of organic and inorganic manures, biofertilizers and micronutrient mixture proved better in improving the growth, yield and quality attributes than using inorganic nutrients alone.

\section{Introduction}

Chilli (Capsicum annuum L.) is one of the most important spices cum vegetable crops of the world, it is widely cultivated in the warm, humid, tropical and subtropical countries. Being an important commercial crop, it finds diverse utilities as spice, condiment, culinary supplement and medicinal value. Chillies are nature's wonder, its fruits appear in various size, shape and colour. Chillies have two important qualities, such as red colour due to capsanthin pigment and biting pungency by capsaicin. India is the largest producer, consumer and exporter of chilli, which contribute to $25 \%$ of total world's production.

Andhra Pradesh is the largest producer of chilli in India, contributes about $30 \%$ to the total area under chilli, followed by Karnataka (20\%), Maharashtra (15\%), Orissa (9\%), Tamil Nadu (8\%) and other states contributing $18 \%$ to the total area under chilli reported (Kumar, 2013).

During cultivation of chilli indiscriminate and 
continuous application of chemical fertilizers resulted in ecological imbalance with consequent ill effects on soil as well as environment and increases the cost of cultivation. Chilli production has to be increased primarily from enhancing the productivity with a combination of high yielding plant types, standard agronomic practices like seed priming and balanced plant nutrition attained through integrated nutrient management (INM). Since chemical fertilizers alone will not be able to sustain the productivity, among which balanced nutrition is one of the most important factor that affecting the growth and productivity of chilli. Hence off late, lot of importance is given to integrated nutrient management. Therefore this study has been conducted to ensure the nutrient requirement of the crop by integration of organic, inorganic and biofertilizers which helps not only to increase the yield but also maintains the soil health and ecofriendly environment. In this context, the INM practice is quite encouraging.

\section{Materials and Methods}

The present investigation was carried out at College of Horticulture Mudigere during October 2016 to March 2017 to test the potentiality of biofertilizers on chilli namely Azospirillum, PSB, VAM, KSB, along with $\mathrm{MgSO}_{4}$ and micronutrient mixture. The experiment was laid out in randomized complete block design (RCBD) with three replications. The seeds of Arka Supal were sown in the nursery. 40 days seedlings were transplanted in ridge and furrow method at spacing of $60 \times 45 \mathrm{~cm}$. At the time of transplanting seedling were dipped in bioinoculants according to treatments and after 10 DAT, $100 \mathrm{~g}$ of solid biofertilizers are mixed with $1 \mathrm{~kg}$ of FYM and applied to individual plot. Whereas $\mathrm{MgSO}_{4}$ applied as soil application@12.5 kg /acre after the one week of transplanting. Well decomposed
FYM @ 25 tonnes per hectare was applied at the time of land preparation. The recommended dose of 150:75:75 kg NPK/ha was applied in the form of urea, single super phosphate and muriate of potash, respectively. The micronutrient mixture (vegetable specialIIHR) which contains all the secondary nutrients like boron, zinc, calcium, sulphur and copper was applied as foliar application at 15 days interval gap during 35, 50 and 65 days of the cop growth stage with dosage of $6.5 \mathrm{~g} /$ liter of water. The data on various biometrical parameters recorded during the period of investigation was tabulated and subjected to statistical analysis. The test of significance (' $\mathrm{f}$ ' test) and critical difference (CD) were read at 0.05 probability.

The treatment details as follows

$$
\begin{aligned}
& \mathrm{T}_{1}-\mathrm{RDF} \text { (Control) } \quad \mathrm{T}_{8}-\mathrm{KSB}+100 \% \mathrm{RDF} \\
& \mathrm{T}_{2-} \text { Azosipirillum }+100 \% \mathrm{RDF} \quad \mathrm{T}_{9}-\mathrm{KSB} \\
& +75 \% \mathrm{~K}+\mathrm{RD} \text { of NP }
\end{aligned}
$$

$\mathrm{T}_{3^{-}}$Azospirillum $+75 \% \mathrm{~N}+\mathrm{RD}$ of $\mathrm{PK} \quad \mathrm{T}_{10^{-}}$ Azospirillum $+\mathrm{PSB}+\mathrm{VAM}+\mathrm{KSB}+$ $75 \% \mathrm{RDF}$

$\mathrm{T}_{4}-\mathrm{PSB}+100 \% \mathrm{RDF} \quad \mathrm{T}_{11}$ - Azospirillum + $\mathrm{PSB}+\mathrm{VAM}+\mathrm{KSB}+50 \% \mathrm{RDF}$

$\mathrm{T}_{5^{-}} \mathrm{PSB}+75 \% \mathrm{P}+\mathrm{RD}$ of $\mathrm{NK} \quad \mathrm{T}_{12^{-}} \mathrm{T}_{10}+$ $\mathrm{MgSO}_{4}+$ Micronutrient mixture

$\mathrm{T}_{6^{-}} \mathrm{VAM}+100 \% \mathrm{RDF} \quad \mathrm{T}_{13^{-}} \mathrm{T}_{11}+\mathrm{MgSO}_{4}+$ Micronutrient mixture

$\mathrm{T}_{7^{-}} \mathrm{VAM}+75 \% \mathrm{P}+\mathrm{RD}$ of $\mathrm{NK} \quad \mathrm{T}_{14^{-}} \mathrm{RDF}+$ $\mathrm{MgSO}_{4}+$ Micronutrient mixture

\section{Plant height (cm)}

Plant height was recorded at intervals of 30 , 60, 90 DAT and at harvest by measuring the length from the base of the plant (ground level) to the growing tip of the main stem from all the tagged plants and average was 
worked out and expressed in centimeters.

\section{Number of branches}

Numbers of primary as well as secondary branches produced per plant were recorded from tagged plants by counting the number of branches at monthly intervals from 30 DAT to harvest and average was worked out and expressed in numbers.

\section{Number of leaves per plant}

The total numbers of leaves produced in each tagged plant at 30, 60, 90 DAT and at harvest were counted and average was worked out and expressed in numbers.

\section{Leaf area per plant $\left(\mathrm{cm}^{2}\right)$}

Leaf area was recorded by taking 25 leaves evenly from bottom, middle and top portion of the plant using leaf area meter (LICOR portable leaf area meter) at 30,60, 90 and at harvest then average was worked out and expressed in $\mathrm{cm}^{2}$

\section{Leaf area index}

The leaf area index at various stages was calculated by using formula suggested by (Seestak et al., 1971).

Where, $\mathrm{A}=$ Leaf area in $\mathrm{cm}^{2}$ (The leaf area was estimated with the help of a leaf area meter).

$\mathrm{P}=$ Ground area covered by plant in $\mathrm{cm}^{2}$ $\mathrm{LAI}=\mathrm{A} / \mathrm{P}$

\section{Total dry matter (g)}

The data pertaining to total dry matter production (TDM) recorded at 60 and 90 DAT

Fruit length (cm)
Five fruits were used for determining the fruit length. Length from base to the tip of the fruit measured using metric scale, averaged and expressed in centimeters as length of the fruit.

\section{Fruit girth $(\mathrm{cm})$}

Five fruits selected for determining the fruit weight and fruit length were used for determining the fruit girth. The girth of the individual fruit was measured at the centre of the fruit with the help of thread and scale average fruit expressed in centimeters as girth of the fruit.

\section{Fresh weight fruit per plant (g)}

Tagged plants from each treatment were selected and harvest the mature green fruits. The average of harvested tagged plant fruits weight was recorded as fresh weight of fruits per plant and expressed in grams.

\section{Fruit yield per plant (g)}

The weight of fruits per plant harvested from randomly tagged five plants from each treatment and each replication was noted down at each picking. The total weight of fruits harvested in each picking was computed, averaged and expressed in weight per plant in grams

\section{Fruit yield per plot (Kg)}

The weight of fruits harvested from each picking was recorded from each plot (including the tagged plants) and total yield per plot was estimated by adding the yield of all the harvest expressed in kilograms per plot.

\section{Yield per hectare (t)}

Fruits harvested in each plot from all pickings were measured in kilograms. Yield per hectare was calculated by using following 
formula and expressed in tonnes per hectare.

Fruit yield $=\frac{\text { Plot yield }}{\text { Plot area }} \times \frac{10000}{1000}$

\section{Chlorophyll content in leaf (SPAD units)}

Chlorophyll content of leaf was analyzed by spad meter. Collect the healthy, fully opened and matured leaves and insert the spad meter to the middle and bottom portion of the leaf at peak growth stage and recorded the value of randomly selected five plant and it expressed in spad units.

\section{Capsaicin content in fruit $(\%)$}

Dry chillies were ground and powdered through sieve No.40. This chilli powder was used to determine the capsaicin content using spectrophotometer method developed by (Palacio, 1979)

\section{Procedure}

Two grams of chilli powder was placed in $100 \mathrm{ml}$ of volumetric flask and diluted to make up the volume with "ethyl acetate". It was allowed to stand for 24 hours to extract the capsaicin.

One milliliter of the extract was diluted to five milliliters with ethyl acetate. Just before reading $0.5 \mathrm{ml}$ of 0.5 per cent vanadium oxychloride ( $\mathrm{VOCl} 3$ ) solution in ethyl acetate was added and shaken. The optical density of the solution was read at $720 \mathrm{~nm}$ in spectronic20. Standard curve was prepared by using 0.5 , 1.0, 1.5, 2.0 and $2.5 \mathrm{ml}$ of standard capsaicin solution containing 50, 100, 150, 200 and 250 $\mu \mathrm{g}$ capsaicin respectively.

Percent capsaicin $=\frac{\mu \mathrm{g} \text { capsaicin }}{100 \times 1000} \times \frac{100}{1} \times \frac{100}{2}$

\section{Ascorbic acid content (mg/ 100g)}

Samples of the mature green fruits were analyzed for their ascorbic acid content using 2, 6-dichlorophenol visual method (Thimmaiah, 1999). The green fruits were cut into two to three $\mathrm{mm}$ pieces and two gram sample was blended with 0.4 per cent oxalic acid and filtered through muslin cloth. To an aliquot of the extract $(2 \mathrm{ml})$ of the sample, 3 $\mathrm{ml}$ acid mixture was added and titrated against the standard dye; the end point is the appearance of pink colour (V2). Similar procedure was followed against acid mixture to get blank titre value and against standard solution made in 0.4 per cent oxalic acid to get standard titre value $\left(\mathrm{V}_{1}\right)$.

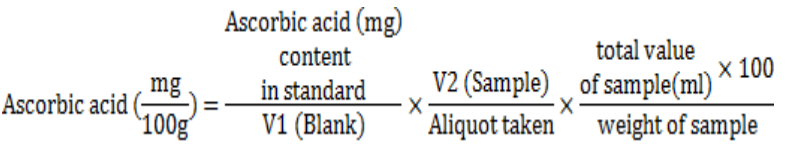

\section{Results and Discussion}

The growth parameters of chilli were significantly influenced by different nutrient management practices and biofertilizers amendments at all the growth parameters are presented in the Table 1.

Significantly higher plant height $(88.61 \mathrm{~cm})$ was recorded in the plants which supplied with Azospirillum + PSB + VAM + KSB + $75 \% \mathrm{RDF}+\mathrm{MgSO}_{4}+$ Micronutrient mixture $\left(\mathrm{T}_{12}\right)$ and it was on par with $\mathrm{T}_{6}(78.62 \mathrm{~cm})$, $\mathrm{T}_{10}(84.08 \mathrm{~cm}), \mathrm{T}_{11}(81.27 \mathrm{~cm})$ and $\mathrm{T}_{13}$ (84.53). Whereas lower plant height was recorded in $(\mathrm{RDF}) \mathrm{T}_{1}(65.33 \mathrm{~cm})$. The results of present investigation are in close conformity with the findings of (Deshpande $e t$ al., 2010). The results suggest that, the combined application of inorganic fertilizers biofertilizers and micronutrient mixture was superior with respect to plant height compared to individual application (Malik et al., 2011).

The application of Azospirillum + PSB + 
$\mathrm{VAM}+\mathrm{KSB}+75 \% \mathrm{RDF}+\mathrm{MgSO} 4+$ Micronutrient mixture $\left(\mathrm{T}_{12}\right)$ resulted in significantly higher number of primary as well as secondary branches per plant (11.22 and 18.44 , respectively) compared to RDF ( 6.78 and 11.33 , respectively). The production of more number of primary as well as secondary branches per plant could be due to higher metabolic activity because of optimum nitrogen supplied by Azospirillum and VAM fertilizers resulting in higher production of carbohydrates and phytohormones like NAA and cytokinins might have resulted in breaking of apical dominance and accelerated higher number of branches. The findings are in line with the results of Medhe et al., (2010), Deshpande et al., (2010), Hiraguli and Allolli (2005).

With respect to leaves as food manufacturing factory of plant and leaf area a site of photosynthesis is responsible for variation in the yield. Significant results were found among the different treatments, maximum number of leaves (298.87), leaf area $\left(10578.06 \mathrm{~cm}^{2}\right)$, leaf area index (3.92) and total dry matter $(118.48 \mathrm{~g} /$ plant $)$ were recorded in Azospirillum + PSB + VAM + $\mathrm{KSB}+75 \% \mathrm{RDF}+\mathrm{MgSO}_{4}+$ Micronutrient mixture $\left(\mathrm{T}_{12}\right)$ compared to $\mathrm{RDF}\left(\mathrm{T}_{1}\right)$.

The maximum number of leaves in this treatment could also be attributed to the increased availability of nitrogen, which is an important constituent of chlorophyll and proteins leads to more growth. Further, it might also be due to the presence of growth promoting substances produced by biofertilizers which would have accelerated the differentiation of leaf primordial in the apical growing region led to increased production of leaves. The results obtained are in confirmation with the findings of Hiraguli and Allolli (2005) in chilli who reported that, combined application of Azospirillum + PSB
+ FYM+ 25\% RDF significantly increased the number of leaves and LAI. Similar findings were reported by Deore et al., (2010). The increase in total dry matter may be due to increase in number of leaves, plant size and fresh biomass which in turn yields higher dry matter content. This result is in conformity with the findings of Hiraguli and Allolli (2011).

The treatment which received Azospirillum + $\mathrm{PSB}+\mathrm{VAM}+\mathrm{KSB}+75 \% \mathrm{RDF}+\mathrm{MgSO}_{4}+$ Micronutrient mixture $\left(\mathrm{T}_{12}\right)$ produced significantly the maximum fruit length (11.60 $\mathrm{cm})$, fruit girth $(4.80 \mathrm{~cm})$, fresh weight of fruit per plant $(268.89 \mathrm{~g})$, fruit yield per plant $(658.67 \mathrm{~g})$, fruit yield per plot $(13.75 \mathrm{~kg})$ and fruit yield per ha (22.92 t/ha) followed by $\mathrm{T}_{13}$, $\mathrm{T}_{10}$ and $\mathrm{T}_{11}$, respectively compared to $\mathrm{RDF}$ $\left(\mathrm{T}_{1}\right)$ (Table 2). This might be due to better physiological condition of plant and increased population of microflora, thereby enhanced availability of nutrients through mineralization process. Higher yield could be due to the regular supply of nutrients leads to more vegetative growth leading to increase in photosynthetic area, which inturn resulted in more synthesis and accumulation of dry matter in the fruit. Moreover, presence of growth promoting substances such as auxin, gibberllins and cytokinin due to presence of biofertilizers would have also contributed in development and accumulation of sink resulting in better growth and subsequently more number of fruits per plant and maximum fruit yield per hectare. These results are agreement with the results of Kondapanaidu et al., (2009), Hiraguli and Allolli (2011) and Leelarani et al., (2015).

It is evident from the result that application of organic, inorganic nutrients and biofertilizer amandement significantly increased chlorophyll content at peak vegetative stage (Table 3). 
Int.J.Curr.Microbiol.App.Sci (2019) 8(2): 2518-2526

Table.1 Effect of INM on growth characters of chilli

\begin{tabular}{|c|c|c|c|c|c|c|c|}
\hline Treatments & $\begin{array}{l}\text { plant height } \\
\text { (cm) }\end{array}$ & $\begin{array}{l}\text { Number } \\
\text { of } \\
\text { primary } \\
\text { Branches } \\
\text { /plant }\end{array}$ & $\begin{array}{c}\text { Number of } \\
\text { secondary } \\
\text { branches } \\
\text { /plant }\end{array}$ & $\begin{array}{l}\text { Number of } \\
\text { leaves/plant }\end{array}$ & $\begin{array}{c}\text { Leaf area } \\
\left(\mathrm{cm}^{2}\right)\end{array}$ & $\begin{array}{l}\text { Leaf } \\
\text { Area } \\
\text { Index } \\
\text { (LAI) }\end{array}$ & $\begin{array}{c}\text { Total Dry } \\
\text { matter/plant } \\
\text { (g) }\end{array}$ \\
\hline$T_{1}$ & 65.33 & 6.78 & 11.33 & 226.67 & 6431.9 & 2.27 & 87.32 \\
\hline $\mathbf{T}_{2}$ & 74.83 & 7.78 & 15.11 & 250 & 8058.1 & 2.98 & 95.36 \\
\hline $\mathbf{T}_{3}$ & 70.57 & 7.44 & 14.44 & 243 & 7183.75 & 2.63 & 91.81 \\
\hline $\mathbf{T}_{4}$ & 76.53 & 7.56 & 14.67 & 233.67 & 6797.23 & 2.52 & 97.07 \\
\hline $\mathbf{T}_{5}$ & 72.1 & 7.33 & 14.11 & 227.8 & 6473.89 & 2.34 & 92.71 \\
\hline$T_{6}$ & 78.62 & 9.00 & 15.89 & 240.77 & 7477.63 & 2.77 & 100.55 \\
\hline $\mathbf{T}_{7}$ & 72.13 & 8.33 & 15.22 & 236.83 & 6953.08 & 2.58 & 97.48 \\
\hline $\mathbf{T}_{8}$ & 71.63 & 7.78 & 14.56 & 236 & 7102.36 & 2.63 & 99.28 \\
\hline $\mathrm{T}_{9}$ & 69.6 & 7.11 & 14.11 & 225.83 & 6470.7 & 2.52 & 93.96 \\
\hline$T_{10}$ & 84.08 & 9.44 & 16.44 & 279.8 & 9581.23 & 3.55 & 108.95 \\
\hline$T_{11}$ & 81.27 & 8.33 & 16.11 & 271.8 & 8613.61 & 3.19 & 103.23 \\
\hline $\mathbf{T}_{12}$ & 88.61 & 11.22 & 18.44 & 298.87 & 10578.1 & 3.92 & 118.48 \\
\hline$T_{13}$ & 84.53 & 9.67 & 16.78 & 281.77 & 9183.06 & 3.4 & 112.74 \\
\hline$T_{14}$ & 75 & 7.89 & 15.56 & 219.33 & 6697.3 & 3.48 & 99.77 \\
\hline S.Em \pm & 3.84 & 0.53 & 0.91 & 14.39 & 471.34 & 0.14 & 4.18 \\
\hline CD@5\% & 11.18 & 1.53 & 2.64 & 41.84 & 1370.17 & 0.4 & 12.16 \\
\hline
\end{tabular}

Table.2 Effect of INM on yield characters of green chilli

\begin{tabular}{|c|c|c|c|c|c|c|}
\hline Treatments & $\begin{array}{c}\text { Fruit } \\
\text { length } \mathbf{( c m )}\end{array}$ & $\begin{array}{c}\text { Fruit } \\
\text { girth } \\
\text { (cm) }\end{array}$ & $\begin{array}{c}\text { Fresh } \\
\text { weight of } \\
\text { fruit/plan } \\
\text { t } \mathbf{( g )}\end{array}$ & $\begin{array}{c}\text { Fruit } \\
\text { yield } \\
\text { /plant }(\mathbf{g})\end{array}$ & $\begin{array}{c}\text { Yield/ } \\
\text { plot (kg) }\end{array}$ & $\begin{array}{c}\text { Yield/ha } \\
\text { (t) }\end{array}$ \\
\hline $\mathbf{T}_{\mathbf{1}}$ & 7.53 & 3.6 & 188.67 & 430.67 & 9.16 & 15.27 \\
\hline $\mathbf{T}_{\mathbf{2}}$ & 9.29 & 3.92 & 202.78 & 494 & 10.4 & 17.33 \\
\hline $\mathbf{T}_{\mathbf{3}}$ & 8.74 & 3.63 & 188.89 & 458.33 & 9.72 & 16.2 \\
\hline $\mathbf{T}_{\mathbf{4}}$ & 8.72 & 4.38 & 208.88 & 499.33 & 10.64 & 17.73 \\
\hline $\mathbf{T}_{\mathbf{5}}$ & 8.59 & 3.94 & 197.22 & 457.33 & 9.3 & 15.5 \\
\hline $\mathbf{T}_{\mathbf{6}}$ & 8.48 & 3.93 & 219.44 & 520 & 11.36 & 18.93 \\
\hline $\mathbf{T}_{\mathbf{7}}$ & 8.17 & 3.48 & 208.89 & 488.33 & 10.44 & 17.4 \\
\hline $\mathbf{T}_{\mathbf{8}}$ & 9.77 & 4.61 & 231.11 & 576.67 & 12.07 & 20.12 \\
\hline $\mathbf{T}_{\mathbf{9}}$ & 9.12 & 4.08 & 215 & 515 & 11.7 & 19.5 \\
\hline $\mathbf{T}_{\mathbf{1 0}}$ & 10.83 & 4.69 & 240.56 & 600.1 & 12.66 & 21.1 \\
\hline $\mathbf{T}_{\mathbf{1 1}}$ & 10.54 & 4.5 & 218.89 & 574.4 & 12.2 & 20.33 \\
\hline $\mathbf{T}_{\mathbf{1 2}}$ & 11.6 & 4.8 & 268.89 & 658.67 & 13.75 & 22.92 \\
\hline $\mathbf{T}_{\mathbf{1 3}}$ & 11.25 & 4.72 & 244.44 & 628.33 & 13.28 & 22.13 \\
\hline $\mathbf{T}_{\mathbf{1 4}}$ & 10.3 & 4.63 & 218.33 & 555 & 12 & 20 \\
\hline $\mathbf{S . E m \pm}$ & 0.57 & 0.25 & 13 & 32.16 & 0.74 & 1.23 \\
\hline $\mathbf{C} \mathbf{D} @ \mathbf{5} \%$ & 1.66 & 0.72 & 37.78 & 93.5 & 2.15 & 3.58 \\
\hline
\end{tabular}


Table.3 Effect of INM on quality characters of chilli

\begin{tabular}{|c|c|c|c|}
\hline Treatments & $\begin{array}{c}\text { Chloropyll } \\
\text { content in leaves } \\
\text { (SPAD units) }\end{array}$ & $\begin{array}{c}\text { Ascorbic acid } \\
\text { content } \\
\text { (mg/100g) }\end{array}$ & $\begin{array}{c}\text { Capsaicin } \\
\text { content }(\mathbf{\%})\end{array}$ \\
\hline $\mathbf{T}_{\mathbf{1}}$ & 56.33 & 110.67 & 0.22 \\
\hline $\mathbf{T}_{\mathbf{2}}$ & 63.86 & 124 & 0.3 \\
\hline $\mathbf{T}_{\mathbf{3}}$ & 62.89 & 116.67 & 0.25 \\
\hline $\mathbf{T}_{\mathbf{4}}$ & 61.37 & 123.33 & 0.32 \\
\hline $\mathbf{T}_{\mathbf{5}}$ & 59.77 & 111.33 & 0.26 \\
\hline $\mathbf{T}_{\mathbf{6}}$ & 69.79 & 127.17 & 0.34 \\
\hline $\mathbf{T}_{\mathbf{7}}$ & 66.77 & 121.33 & 0.31 \\
\hline $\mathbf{T}_{\mathbf{8}}$ & 63.13 & 130 & 0.34 \\
\hline $\mathbf{T}_{\mathbf{9}}$ & 60.29 & 126.67 & 0.31 \\
\hline $\mathbf{T}_{\mathbf{1 0}}$ & 72.4 & 135.63 & 0.36 \\
\hline $\mathbf{T}_{\mathbf{1 1}}$ & 71.7 & 129.93 & 0.33 \\
\hline $\mathbf{T}_{\mathbf{1 2}}$ & 79.74 & 141.27 & 0.39 \\
\hline $\mathbf{T}_{\mathbf{1 3}}$ & 75.81 & 138.47 & 0.37 \\
\hline $\mathbf{T}_{\mathbf{1 4}}$ & 73.77 & 118.33 & 0.3 \\
\hline $\mathbf{S . E m \pm}$ & 4.04 & 5.26 & 0.02 \\
\hline $\mathbf{C} \mathbf{D} @ \mathbf{5 \%}$ & 11.73 & 15.3 & 0.06 \\
\hline
\end{tabular}

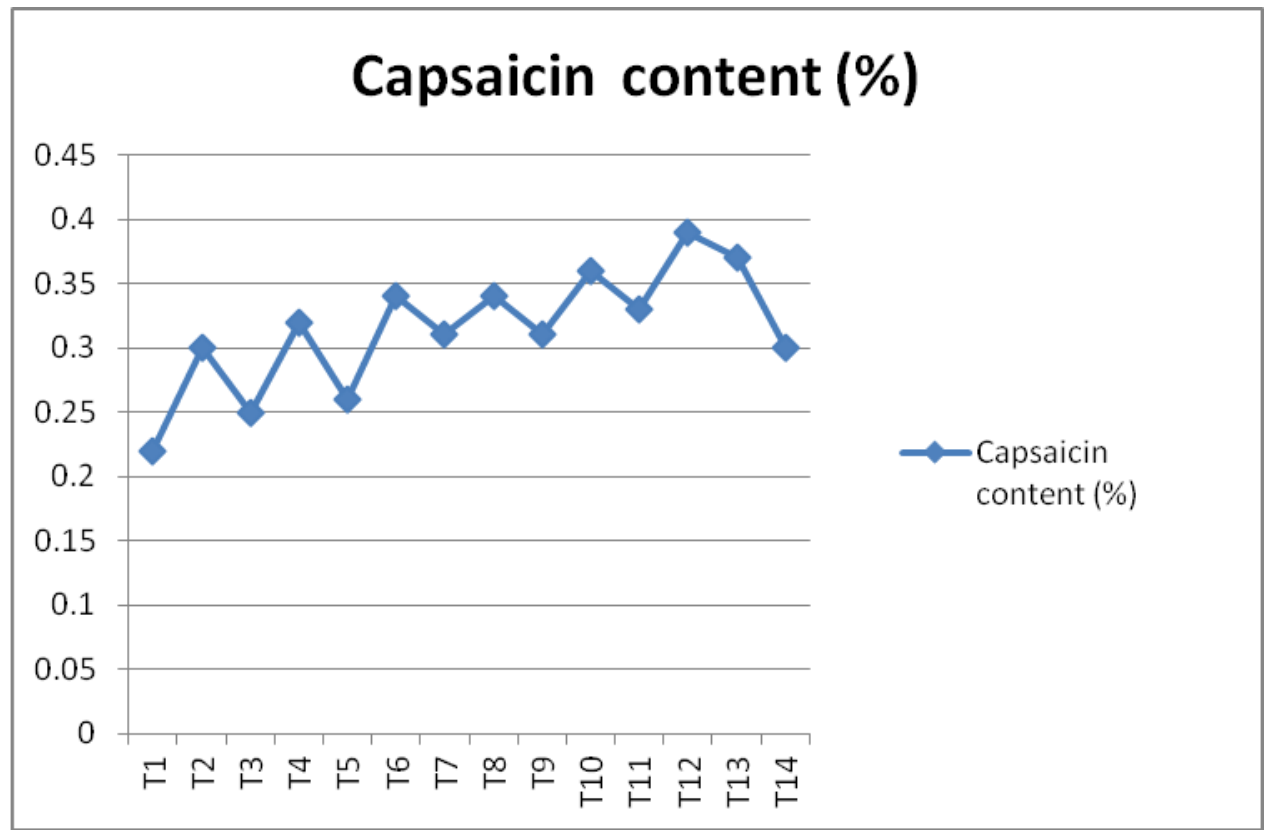

The maximum chlorophyll content (SPAD units) was (79.74) was recorded in Azospirillum + PSB + VAM + KSB + 75\% $\mathrm{RDF}+\mathrm{MgSO}_{4}+$ Micronutrient mixture $\left(\mathrm{T}_{12}\right)$ over RDF (56.33). This might be due to enhanced availability of nutrients, constituent of protein and protoplasm resulting in greater photosynthetic activity. These results are in 
line with the earlier findings of Alaboz et al., (2017).

The ascorbic acid and capsaicin content of chilli differed significantly by adopting different nutrient management practices and application of biofertilizers amendments. Significantly, the highest values were observed in chilli with regard to above characters when it was supplemented with Azospirillum + PSB + VAM + KSB $+75 \%$ $\mathrm{RDF}+\mathrm{MgSO} 4+$ Micronutrient mixture $\left(\mathrm{T}_{12}\right)$ (141.27 $\mathrm{mg} / 100 \mathrm{~g}$ and $0.39 \%$, respectively) followed by Azospirillum + PSB + VAM + $\mathrm{KSB}+50 \% \mathrm{RDF}+\mathrm{MgSO}_{4}+$ Micronutrient mixture $\left(\mathrm{T}_{13}\right)(138.47 \mathrm{mg} / 100 \mathrm{~g}$ and $0.37 \%$, respectively) and lowest was recorded in $\mathrm{RDF} \quad\left(\mathrm{T}_{1}\right) . \quad(110.67 \mathrm{mg} / 100 \mathrm{~g}$ and $0.22 \%$, respectively) It clearly shows that increasing nutritional status increased the ascorbic acid and capsaicin content. It might be due to additional availability of nutrients especially nitrogen by Azospirillum and potassium by $\mathrm{KSB}$ which are responsible for synthesis and accumulation nutrient quality of fruits and also the increase in capsaicin content by the application of INM might be due to physiological influence of Azospirillum, PSB, VAM and KSB on the activity of a number of enzymes, which play an important role in biosynthesis and accumulation of capsaicin alkaloids in chilli. These results are in conformity with the findings of Naveen et al., (2009). Therefore present investigation concluded that application of Azospirullum + $\mathrm{PSB}+\mathrm{VAM}+\mathrm{KSB}+\mathrm{MgSO} 4+$ micronutrient mixture $+75 \% \mathrm{RDF}$, has more beneficial effects in terms of growth yield and quality attributes of chilli as compared to application of recommended dose of NPK fertilizers (RDF) under field condition.

\section{References}

Alaboz, P., Ahmet, A. I., Metin M and Senol H., 2017. Effects of different vermicompost and soil moisture levels on pepper (Capsicum annuum). Soil Sci and Pls Nutrition., 27: 30-36.

Deore, G. B., Limaye, A. S., Shinde B. M and Laware S. L., 2010. Effect of novel organic liquid fertilizer on growth and yield in chilli (Capsicum annuum L.). Asian Exp Bio Sci pls., 3: 15-19.

Deshpande, R. P., Tamgadge, S., Deshmukh, A and Deshmukh S., 2010. Effect of organic and inorganic manures on growth and yield of chilli. Inter. J. For \& Crop Improvement., 1: 146-148.

Hiraguli, P. S. and Allolli, T. B., 2011. Response of organic, inorganic and bioferilizers on growth and yield of chilli. The Asian J Hort., 6: 352-354.

Kondapanaidu, D., Radder, B. M, Patil, P. L., Hebsur, N. S and Alagundagi SC., 2009. Effect of INM on yield, nutrient uptake and quality of chilli $(\mathrm{Cv}$. Byadgi Dabbi) in a vertisol. Karnataka J Agric Sci ., 22: 438-440.

Kumar, A. K., 2013. Effect of foliar application of NPK nutrients on growth and yield of chilli (Capsicum annuum L.). $J$ Res Acharya $N G$ Ranga Agric Univ., 41: 1-4.

Leelarani, P., Balaswamy, K., Rao, A and Masthan, R. S. C., 2015. Evaluation of integrated nutrient management practices on growth, yield and economics of green chilli $\mathrm{Cv}$. Pusa Jwala (Capsicum annuum L.). Int $J$ Bio-resource \& Stress Management., 6: 76-80.

Malik, A. A., Chattoo, M. A., Sheemar, G and Rashid, R., 2011. Growth, yield and fruit quality of sweet pepper hybrid SH-SP-5 (Capsicum annuum L.) as affected by integration of inorganic fertilizers and organic manures (FYM). J Agric Tech., 7: 1037-1048.

Medhe, N. K., Gawade, B. V., Randive, S. N and Temkar, B. G., 2010. Effect of 
integrated nitrogen management on yield and economics of green chilli (Capsicum annuum L.) production. Green Farming., 1: 260-262.

Naveen, N. E., Panneerselvam, S., Anand, S. R., Sathyamorthi, K and Meena, S., 2009. Effect of organic manures on the yield and quality of green chillies (Capsicum annuum L.). Res. on crops., 10: 621-625.

Palacio, J. R. R., 1979. Analysis of capsaicin.
J. Association of Anal. Chem., 60: 970-974.

Seestak, Z., Catasky, J and Jarvis, P. G., 1971. Plant photosynthetic production manual of methods. Ed. Junk, N.V., The Haque Publishers, pp. 343-381.

Thimmaiah, S. R., 1999. Standard method of biochemical analysis. Kalyani publishers New Delhi, pp. 278-279.

\section{How to cite this article:}

Yogaraju, M., V. Srinivasa, Y.M. Mahadevprasad and Devaraju. 2019. Integrated Nutrient Management Studies on Growth, Yield and Quality Attributes in Chilli (Capsicum annuиm L.). Int.J.Curr.Microbiol.App.Sci. 8(02): 2518-2526. doi: https://doi.org/10.20546/ijcmas.2019.802.293 